By MARTHA S. BELL

\title{
Collection of Writings by Virginia Women
}

$\mathrm{D}^{2}$ URING the past seven years the alumnæ of Randolph-Macon Woman's College have assembled in the college library a group of books which is at once unique in character and valuable in content. The product of resourcefulness and effort on the part of many booklovers, this collection of the writings of Virginia women stands as a revealing cross section of life and thought in the Old Dominion over a period of more than one hundred and twenty-five years.

Randolph-Macon is fortunate in having many library-minded alumnæ. For years their interest has taken tangible form, and both individuals and classes have frequently made generous contributions to be used for the building up of a worth-while group of rare books in the college library. As interest grew and the number of gifts increased, it became evident to the librarian that there should be a system of planned giving, with gifts directed toward a definite project. This matter was discussed by informal groups of alumnæ, faculty members, and friends of the college. Finally, the idea of assembling all the published writings of Virginia women was suggested and accepted by all interested parties.

The plan was definitely formulated in 1938, when it was also officially endorsed by the general alumnæ association. A committee was appointed to direct the enterprise, and the task of organizing the work and getting it under way was given to a graduate of the college who lives in Lynchburg. The enthusiasm of the committee and the untiring efforts of the director, who has made herself an authority on the subject of Virginia women authors, are, in large measure, responsible for the success of the project. Certain alumnæ, however, also stand out conspicuously for the work they have done. One woman, for instance, has been instrumental in obtaining one hundred and two volumes of sixty-three authors.

A word about the method of procedure may be of interest. As a beginning, a tentative mimeographed list of about two hundred names of Virginia women authors was compiled. This list was distributed to all alumnæ who attended the annual alumnæ association meeting held during the 1938 commencement. Each member was asked to consider herself a committee of one to begin a search for the desired books. An expanded list was distributed at the alumnæ meeting the following June. Many names were subsequently added, as more and more Virginia authors came to the attention of the director, and in 1939 a sixteen-page booklet containing the names of 366 Virginia women authors was printed and sent to alumnæ and interested friends. A later development was the compilation of geographical lists which were given out to alumnæ chapters in various localities. This had proved to be an excellent way to acquire books from special sections of the state. Every effort is also being made to obtain accurate biographical data about each author. This information had already been 
completed for more than two hundred writers.

The very character of the enterprise made an immediate appeal to many alumnæ. Individual, self-directed book hunts began to bear fruit as news of the project spread, so that within a year a creditable nucleus of books had been assembled. This small beginning has now grown to proportions beyond the hopes of its sponsors. Funds for the purchase of books have been supplied by gifts from alumnæ.

There are, to date, 840 volumes in the collection, representing the writings of more than three hundred women. Approximately 50 per cent of the books have been contributed by the authors and their relatives, who seem to be unusually interested in the project. Many of the volumes are the result of trips into unfrequented attics, to private and church libraries, and to bookshops, large and small. In the course of searches pleasant personal contacts have also been made.

\section{All-inclusive Collection}

The official name of this group of books is "The Collection of the Writings of Virginia Women." The term, "Virginia Women," has been defined to include women born in Virginia and those who, through years of residence, have become identified with the state. Books and manuscripts are being collected. No attempt has been made, so far, to obtain writings which have appeared in periodicals or anthologies. It is planned to make the collection all-inclusive. Interest is not in "literary worth" as such; efforts are made to bring together a group of books that will be a permanent record of the thoughts, ambitions, and achievements of the women of Virginia.

The interests of these women have ranged widely. Treatises on sociological problems and learned historical studies stand beside "mammy" stories and intimate, personal diaries. Lengthy genealogies are shelfmates with slim volumes of poetry; admonitions to young ladies of the Old South and books on "female character" occupy places near modern mystery stories and recent best sellers.

The earliest published volume in the collection, The Potomac Muse, "by a Lady, a Native of Virginia" (Mrs. Alfred W. Elwes), appeared in 1825 . This was followed a year later by Anne Royall's Sketches of History, Life and Manners in the United States. The latter and seven other of Mrs. Royall's shrewd, outspoken, often vituperative writings are probably the most valuable books in the entire group, from the standpoint of rare items.

Women published comparatively few books in the early nineteenth century. The important opus, Flora's Dictionary, valuable volumes on Indian life by Mary Eastman, and occasional books of sentimental, saccharine verse were produced, but it was not until after the Civil War that any extensive contribution to the book world was made. The postwar years brought forth many memoirs, journals, autobiographies. These form a clear, vital record of the hardships and suffering experienced by the women of the Confederacy and testify to their courage and gallantry in the face of great difficulties. Many novels also appeared during this period-stories of love and adventure, romances of devotion and self-sacrifice, tales of Negro and plantation life. By the turn of the century, several presses were bringing out the works of Virginia women. As time goes on, contemporary writers are producing scores of volumes covering various forms of literary expression.

\section{Types and Subjects}

It is worth noting that special types of 
books and certain subjects appear throughout the collection, cutting across all period barriers. For instance, Virginia women have written books for children since 1854 . (This group of books, incidentally, was used as an effective exhibit in the RandolphMacon Library during Book Week.) Cookbooks provide sidelights on the social life of the times, from early days to the present; various versions of the Pocahontas story have appeared in poem and story since I 840 ; gardening has always been an interest of Virginia women.

The many delightful features of this record of the past and present might be developed indefinitely. This will, however, give some indication of the wealth and breadth of its material. It is the desire of the alumnæ association to make the recoid complete for the past, active in the present, and to have it project into the future. Although much work remains to be done, there is no letup in the search for desired items. All who now have a part in collecting the books find great satisfaction in their efforts and, in the years ahead, see great possibilities for carrying onward this memorial to the women writers of Virginia.

\section{Authors' Names in Negro Collections}

\section{(Continued from page 342)}

bibliographical, biographical, or historical. concerning Negro writers, should report such information to the Union Catalog. ${ }^{10}$

3. Libraries containing special Negro collections should check with each other items of bibliographical importance not settled by the Union Catalog.

4. Librarians should file with editors of Negro periodicals their approval of the proposed recommendations for the standardization of periodical publishing, emphasizing the point that full names of authors and coauthors be used whenever possible. ${ }^{11}$ Editors might also be requested to indicate racial identity in describing their contributors.

5. Whenever the opportunity presents itself, the librarian should urge the authors of worthwhile titles which have not been copyrighted to present copies of those works to the Library of Congress. This would result in an in-

${ }^{10}$ Ibid., p. 9-10. Directions as to what to report and

how to report it. Manle, J. H. Manul of Serials Work, p. 53. creased usefulness of the Library of Congress file of Negro authors.

\section{Suggestions for Further Study}

In the interest of providing tools for the use of the cataloger, which will prove equally useful to the research student and the reading public, these suggestions for further studies are offered:

I. The compilation of an adequate bibliography of Negro literature, with full main entries, indicating racial identity, necessary cross references, and full indexing.

2. The compiling and editing of an authoritative biographical dictionary of the Negro race.

3. A history of Negro literature from 1900 to date.

4. The compilation and annotation of a checklist of writings of the Negro authors of South America, Haiti, and Cuba, with adequate main entry information. 